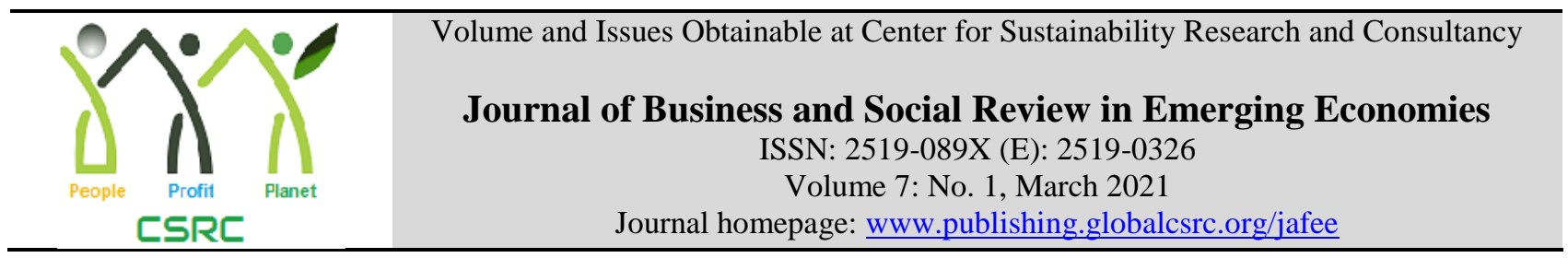

\title{
Child Labour in Pakistan: Way out Analyzing Constitutional Mandate
}

*Barkat Ali, Department of Law, the Islamia University of Bahawalpur, Pakistan

Shaukat Hussain Bhatti, Department of Law Times Institute, Multan, Pakistan

Fazli Dayan, Department of Shariah \& Law, Islamia College (University) Peshawar, Pakistan

*Corresponding author's email address: barkatali27@gmail.com

ARTICLE DETAILS ABSTRACT

History

Revised format: Feb 2021

Available Online: Mar 2021

Keywords
Child Labor, Right,
Constitution, Pakistan,
Convention.

JEL Classification: MO, MI

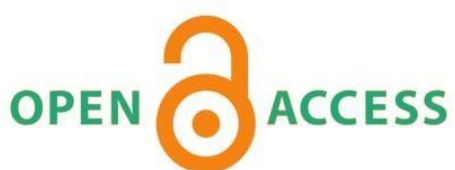

Purpose: Child Labor is the worldwide social issue. The study undertaken attempts to identify the reasons behind child labour and to assess the socio-economic related problems faced by the working children. This study further analysis the effectiveness, sufficiency and potential of the constitutional provisions concerning children's rights as committed in the Constitution, 1973.

Findings: In Pakistan, child labour is not only prohibited, it is discouraged by providing a free compulsory education, self-respect and social welfare. Though, these provisions are healthy sign, but are not comprehensive on child labour particularly for determining the minimum age and nature of work. Even these provisions are not clear, and harmonious with one another.

Implications: Furthermore, the ordinary laws are not in compatibility mode of the constitutional provisions. Such complications are both about child and child labour definition. So, it is suggested to have a single common standard of these two basic factors in child labour context for saving the children from indulging in child labour in Pakistan.

(C) 2021 The authors, under a Creative Commons AttributionNonCommercial 4.0

Recommended citation: Ali, B., Bhatti, S. H. \& Dayan, F. (2021). Child Labour in Pakistan: Way Out Analyzing Constitutional Mandate. Journal of Business and Social Review in Emerging Economies, 7(1), 201-208.

\section{Introduction}

A child is an integral part of the society. He is the credible source for societal development. The children have a great potential for originating the society's future. The constructive use of children's faculties has a crucial rule for children's as well as society's over all development. Yet, a considerable number of children is used for materialistic benefits. Such trend affects their socio-economic development adversely. They are exposed to the materialistic situations where they serve a number of functions in hazardous conditions.

This is worldwide prevalent and alarming situation, and Pakistan is no exception. It has become a complex socio-economic issue affecting the fundamental human rights of children. It is frustrating their 
educational, psychological and physical development. This social phenomenon is fettering the socioeconomic development particularly the equitable growth of the nation. This state of affairs, indeed, result the engendering of an illiterate and relatively unskilled labour force, and thus surfacing the perpetuate poverty and worthless society.

This social phenomenon has become as per view of Luna "The challenge ...to help these children." (Luna, 2019). It calls for the elimination as realized by all stack holders that "Children are vulnerable and it is our duty to lead their way to provide them the opportunities that they deserve" (Luna, 2019). But how? For this query, this paper aims to explore the effectiveness of the prevailing legislative measures particularly the constitutional law on the subject of child labour in term of the question, 'Whether the constitutional mandate concerning children's rights as provided in Constitution, 1973 has potential for capacity-building for controlling child labour in Pakistan."

In the above context the study undertaken attempts to identify the reasons behind child labour and to assess the socio-economic related problems faced by the working children. This study further analysis the effectiveness, sufficiency and potential of the constitutional provisions concerning children's rights as committed in the Constitution, 1973. Further, this study aims the making of deficiency, if any, through identifying the shortcomings therein by supplementing the prevalent constitutional provisions in Constitution, 1973.

\section{Child Labor: Conceptual Understanding}

Plato did rightly observe that "One cannot incorrigibly use a term let alone preach about it unless it is known what that term refers to." (Plato, 1987, 217). A precise understanding is central for discussing and analyzing any problems, their nature, trends and extent. Defining and explaining the basics of a problem, makes it possible to conclude the reasons and resolution thereof. Similar, seems the matter of the Child labour, the issue in hand.

The issue of child labour though is centuries old (Cunningham \& Viazzo, 1995; Prügl, 1999, 25-31, 5059); Hindman, 2009); The Health and Morals of Apprentices Act, 1802), the concept is yet vague. The conceptual understanding of child labour both in the international community and Pakistani context is not clear. Rather it is ambiguous and confusing. The conceptual vagueness indeed has affected the efficacy of the concerned legislation either at national or international level. Explaining the notion of Child labour, seems substantial for understanding its multifaceted connotations and diversified problems particularly in Pakistan. It will have a critical bearings for reaching any practical oriented conclusion and on designing policies to control the issue of child labour.

It, therefore, requires the conceptual clarification before dwelling on the critical analysis of constitutional mandate for child labour in Pakistan. Under these lines child labour related two basic concepts, i.e., 'Childhood' and 'Child labour' are explained which provides a foundation for concluding the critical analysis as undertaken in this study.

\section{Childhood}

The parameter for determining the childhood in context of child labour is not the same worldwide. It varies from state to state. Even within the same state, legal systems have no uniform policy regarding the age for childhood. There are, indeed, different considerations for declaring a person as child for different purposes. This situation is endorsed by the social scientists. They are of view that a child is not essentially expressed by a fixed limit of age. Rao observes that "child's abilities and maturities vary so much that defining a child's maturity by calendar age can be misleading" (Rao, 2020, 83).

Of course, attempts have been made to define and determine childhood. Biologically, child is described as "a human being between the stages of birth and puberty" (Mosby, 2016, 345). Rathus outlines the child as a person "between the development period of infancy and puberty" (Rathus, 2013, 48). The laws 
are made with different objectives in a particular context of the country concerned. So, the child has been defined differently in different laws in different countries. In Indian jurisprudence, there are the different definitions of child in different laws (The Protection of Children Act, 2012, Section 2(d); The Beedi and Cigar Workers Act, 1966, Section 2(b); The Child Labour Act, 1986, 2(ii)). In legal system of UK such age limit is 16 years (The Children and Young Persons Act 1933). There are different age limits for child in child labour context in USA. (Child Labor Regulation Under the Fair Labor Standards Act, 1938).

The same is the position of Pakistan. The Constitution, 1973, a fundamental law, asserts for the fundamental rights of a child in contexts of education and hazardous employment and equality (Articles 11(3), 14 25(2), 26(2). In addition there are certain principles of policy as well for promoting of children's interest (Article 35 and 37 (e)). However, child has not been defined elsewhere in the Constitution. Of course, for determining the childhood the reference may be made of Articles 11(3) and 25-A, Constitution, 1973. Both of these Articles are contextual, having no standard criterion for childhood. The relevant constitutional provision provides that "No child below the age of fourteen years shall be engaged in any factory or mine or any other hazardous employment."(The Constitution, 1973, Article, 11). Whereas Article 25-A of the same constitution dealing with the right to education proclaims that "The State shall provide free and compulsory education to all children of the age of five to sixteen years."

Among ordinary laws, the Majority Act 1875 decides the borderline for the childhood in a sense that "... every other person domiciled in Pakistan shall be deemed to have attained his majority when he shall have completed his age of 18 years and not before."(Section 3, Paragraph 2). The same is the age standard for guardianship under Section 3 of the Guardian and Ward Act, 1890. For the worker, the Factories Act 1934, proclaims that "child means a person who has not completed his fifteenth year."(Section 2 (c)). For a person working in a mine a child, "means a person who has not completed his fifteenth year" (The Mines Act 1923, Section 3 (c)). The Shops and Establishment Ordinance 1969, describes a child as a "person who has not completed his fourteenth year of age." (Section 2 (c)). The Employment of Children Act, 1991 as amended in 2005, defines child as "a person who has not completed his fourteenth year of age."(Section 2 (iii)). For the recruitment of soldiers either as Jawans or Officers the age limit is from17 and 23 years. (The Pakistan National Service Ordinance of 1970). Regarding the human trafficking "child means any- person who has not attained the age of eighteen years" The Prevention and Control of Human Trafficking Ordinance, 2002 Section 2 (b)).

So far as international norms are concerned, these are also not on the same footings concerning age factor for childhood. The Convention on Rights of Children (CRC), 1989 describes that "A child is recognized as a person under 18, unless national laws recognize the age of majority earlier" (Article 1). The Minimum Age Convention,1973, for the minimum age standard asks the member countries to design a national policy "...to ensure the effective abolition of child labour and to raise progressively the minimum age for admission to employment or work to a level consistent with the fullest physical and mental development of young persons." (No. 138, Article 1).For this purpose, the same Convention asserts that "The minimum age ... in any case, shall not be less than 15 years."(No. 138, Article 1). For preventing the worst forms of child labour "...the term child shall apply to all persons under the age of 18.” (The Worst Forms of Child Labour Convention, 1999, No. 182, Article 2).

\section{Child Labour, What is?}

Though the issue of child labour is of universal nature, it lacks a specific comprehensively established definition. Child labour is, indeed, associated to the issues of socialization and economic activities, and as such, it has been explained in different contexts. It is of complex and multifaceted nature involving the matters relating to the work, labor, education and health.

So, as per view of Schlemmer (1997), "the term 'child labor' is pernicious because it depends on a 
definition of both 'work' and 'childhood', thus complicating the task of reaching a precise definition." However, attempts have been made for developing an internationally acceptable definition of child labour. (Edmonds, 2009, 3). Here, we have a brief review of certain connotations of child labour including work and labour as used in academic and research studies.

In general terms child labour is that work which is engaged by the children less than a legally specified age as identified and analyzed above. However, such works as joined by the children are of different types and nature. These types of works include enforced, arduous, dangerous and morally abhorrent work. Child labour is the employment of children which eventually affects their socio-physical development. It, in other words, is a work which frustrate the childhood and the rights therein.

International standards are of their own nature regarding the child labour. These standard have been made on the basis of two different factors, namely, age and nature of work. United Nations, considers the child labour simply as a work which is not suitable for children of a particular age. Such definition is age factor based which generally mentions the children of 15-16 years engaged in full-time employment, and for children below 18 years of age suffering in hazardous work. In describing child labour, the ILO speak of the System of National Accounts that considers the work in terms of economic activities including all paid work as well as domestic tasks. Hence, as per guidelines of ILO every work done by a child is not categorized as child labour (International Programme on the Elimination of Child Labour, 1992). Furthermore, a labour includes the using children for prostitution, illicit activities, slavery, and employment that is dangerous to health, security and moral values (The Worst Forms of Child Labour Convention 1999 (No. 182), Article 3).

In this context ILO defines child labour as "work that deprives children of their childhood, their potential and their dignity, and that is harmful to physical and mental development." (International Programme on the Elimination of Child Labour). In contrast UNICEF delineates child labour as "work that exceeds a minimum number of hours, depending on the age of a child and on the type of work. Such work is considered harmful to the child and should therefore be eliminated". CRC explains child labour as, "Work performed by a child that is likely to interfere with his or her education or to be harmful to their health or physical, mental, spiritual, moral or social development" (CRC, 1989, Article 32(1)).

Some people are of view that for the purpose of child labor 'work' and 'labor' should be separated for achieving the intended objectives of children's development (Seabrook, 2001, 67). So, for designing child labor policy, the nature of the work as well as the nature of the relationship between the employer and child must be measured carefully (Grootaert \& Kanbur, 1995, 5).

\section{Volume of Child Labour in Pakistan: An Overview}

Child labour is a serious issue having multidimensional challenges for the socio-economic development for all countries including Pakistan. In near past, ahuge number of children have been involved in such social evil in Pakistan. According to Mustafa, "Pakistan's Labor Force Survey, 2014-15 showed that of those children aged between 10 and 14 years active in child labor, 61 percent were boys and 88 percent came from rural areas." Though, "Child labor rates across the world have been in rapid decline since the 1950s" (Basu, 1999), children rights have been under serious threat throughout the human history particularly in child labour context. The prevalent critical situation of child labor is deliberated from different aspects viewpoint in these lines. Such discussion will be helpful in concluding the leg impact on child labor in Pakistan.

\section{Child Labour: Possible Preventive Strategies}

Historically, no state has ever been entirely free from child labour. Since, 1990s there has been a worldwide movement for the suppression of this social issue. The word over, governments started designing the policies for confronting and controlling the issue. In this context, different countries in their own socio-economic and legal context have made different strategies. Among these strategies, focusing the economic development, enhancing the literacy rate, compulsory education, and improving 
the life standard are in practice. These dynamics across the countries, since some decades, have played important role in reducing child labor worldwide. (Clark, 2011, 1034). However, the legal measures having their own significance, have become most popular worldwide, are discussed hereunder.

\section{Legal Measures}

Adopting the legislative measures is the significant common approach followed by the governments for avoiding child labor. At country level, the labour laws are made in pursuance of the international conventions. Different countries have developed different legal norms prohibiting the employment activities of children having the age around 14 or below, and controlling the child labor of children up to 17 years (Anker, Barge, Rajagopal \& Joseph, 1998). Legal measures are considered the important options applied successfully by the developed nations. (Angrist \& Krueger, 1991). The law appears to be an effective device for reducing child labour. (Hort, 1989). It is observed that the number of students did increase in school because of child labour laws. (Acemoglu \& Angrist, 1999). These laws include the constitutional law as well. However, in context of the research question, under these lines, only constitutional provisions relating to child labour, are identified and analyzed.

\section{Constitutional Mandate: Retrenching the Child Labour}

Pakistan has made the constitutional commitment to contribute for worldwide socio-economic development of humanity including children community (The Constitution, 1973, Preamble). In this context, it has signed and adopted certain conventions for addressing the child labour issue. Such conventions recognize the right of every child to be escaped from work that is hazardous and exploitative to health and socio-economic development. These legal norms require the governments to set a minimum age for employment and to provide proper working conditions, access to education and address human rights. (The Worst Forms of Child labour Convention, 1999 (No.182); UN Guiding Principles for Business and Human Rights, 2011; The ILO-DFID Asia Regional Child Labour Programme; The ILO Decent Work Country Program (2016-20). Therefore all the relevant provisions of these conventions have become the part of the law of the land in Pakistan.

Pakistan has originally made some other laws as well concerning the subject matter of child labor. Among those the most relevant are the Children Act, 1933, the Employment of Children Act 1991, the Employment of Children Act, 2011, the Employment of Children Rules 1995, the Khyber Pakhtunkhwa Prohibition of Employment of Children Act, 2015, the Punjab Prohibition of Child Labour at Brick Kilns Act, 2016, the Punjab Restriction on Employment of Children Act, 2016, the Sindh Prohibition of Employment of Children Act 2017, the Factories Act, 1934, the Khyber Pakhtunkhwa Factories Act, 2013, the Sindh Factories Act, 2015 and the Punjab Compulsory Education Act 1994.There is also shop and establishments legislation as well, namely, the Shops and Establishments Ordinance, 1969, the Shops and Establishments Ordinance, 1969 , the Khyber Pakhtunkhwa Shops and Establishments Act, 2015, and the Sindh Shops and Commercial Establishment Act, 2015.

In addition to the above, there are also field specific laws dealing with the employment of children. Such legislation regulates the working conditions for child workers like the Mines Act, 1923, the Road Transport Workers Ordinance, 1961, the Merchant Shipping Ordinance, 2001, the Bonded Labor System Abolition Act 1992, the Punjab Prohibition of Child Labour at Brick Kilns Act 2016. These laws either directly or indirectly are concerned with controlling, discouraging and reducing the child labour in Pakistan.

The Constitution is the fundamental law which provides the guidelines and directions for the institutions and individual as well. It is the constitutional duty of government and all other concerned to pursue the constitutional provision in letter and spirit. (Constitution, 1973, Article 5). The constitution, 1973 has provided and guaranteed certain rights for the individuals. These rights include the fundamental rights (Constitution, 1973, Articles 9-28) and principles of policy (Constitution, 1973, Articles 29-40) in addition to other constitutional rights (Constitution, 1973, Articles 2-A, 3, 4). 
The Constitution 1973 has guaranteed fundamental right for children in term of prohibition of child labour.. The constitution proclaims that "... No child below the age of fourteen years shall be engaged in any factory or mine or any other hazardous employment." (Constitution, 1973, Article 11(3).The child labour, indeed, goes against the dignity of child engaged in any inappropriate work. So, again, though indirectly, the child labour has been discouraged in term of upholding the human including child dignity. In this context the Constitution further proclaims that "The dignity of man ... shall be inviolable" (Constitution, 1973, Article 14(1)). The Constitution 1973 also asserts for right to education, more explicitly that, "The State shall provide free and compulsory education to all children of the age of five to sixteen years in such manner as may be determined by law." (Article 25-A).

The principles of policy are next to fundamental rights provided in the Constitution, 1973. These are intended to promote the socio-economic development both in at collective and individual level. In this context, it has been committed by the government that "The State shall protect ...the child." (Constitution, 1973, Article 35). Furthermore it is asserted that "The State shall...make provision for securing just and humane conditions of work, ensuring that children ... are not employed in vocations unsuited to their age or sex...in employment" (Constitution, 1973, Article 37(e)).

Since, the passing of Constitutional $18^{\text {th }}$ Amendment, 2018, child labour was the federal subject matter, and the Federal government was responsible for the addressing and eventually removing this evil phenomenon form the society. Now, it has been transformed to the provinces. Furthermore, in 2011, in addition to the federal government's Employment of Children Act 1991, Punjab government through introducing some amendments in the said statutory law, passed the Employment of Children Act, 2011. Such amendments are appreciated and demanded to be made in other provinces as well for developing uniformity among the provincial laws. (Brackly, 2013). However, these laws must be in consonance with the constitution.

The combined and analytical study of the above three provisions of Articles 11(3), 25-A and 37(e), prove to be a good frame work for handling the issue of child labour. The constitutional provisions relating to the child labour prohibition and free and compulsory education for children are co-related and interdependent. The progressive enforcement of one may be the encouraging step for the guarantee of the other. If, the number of school going students is increased, the number of children joining the child labour will eventually be reduced, and vice a versa the prohibition of child labour may increase the number of school going children. Such constitutional provision promoting the education under Article 25(A) is considered the two-in-one principle. (Mahmood, 2014). However, in this context, it is the constitutional obligation of government to ensure the enforcement of this principle determinedly for the education of all specifically for underprivileged.

These provisions in term of fundamental rights may possibly be utilized for resolving the issue of child labour. So, the government should make the policies keeping in view both of these fundamental rights. In this regard the government itself, without waiting for the initiative on the part of the parties, will have to step in for the enforcement of these two rights jointly. Thus, the principle of policy of protecting the child, (Constitution, 1973, Article 35) will automatically be implemented. This state of affairs will further ensure the implementation of another principle of policy "...ensuring that children ... are not employed in vocations unsuited to their age or sex...in employment" (Constitution, 1973, Article 37(e)). It will, indeed, ensure the upholding of human dignity, liberty and morals, and will reduce materialistic mindset against the exploitation of children, and may result the promotion of socio-economic justice and eradication of social evils like child labour (Rehman, 2011).

However, these constitutional provisions are still neither clear nor comprehensive. Rather, these provisions are self-contradictory and insufficient. Resultantly, such constitutional legislation as such has no effective impact on the measurements taken for the child labour. There is, indeed, no agreement in these provisions on single standard of age limit for declaring a person as a child. The age limit starting 
from 14 to 18 years of age has become a dogging strip for child labour beneficiaries. This situation is creating ambiguity and confusion, and is letting the backdoor for the person using the child for their vested interests. They at the time of need misuse and misinterpret such a huge difference of 4 years. At the receiving end of this ambiguity, are the children, suffering a lot.

In addition to the age factor the child labor is decided through the nature of work engaged by the individual. The works allowed/permitted in national laws are not so decent for the protection of the child personality development and as such are not in consonance with the spirit of the constitution. These works include employments in mines, factories, railway, ports production, processing chemicals and weaving. However, these laws allow joining these types of works subject to certificate of fitness issued by the concerned medical authority. Amount of working hours and timings are other factors deciding the child labour. Again, the prevailing laws on these issues are neither on the same point nor in according to the intention of the constitution makers. This state of affairs, both regarding age and child labour has resulted an adverse effects on the policies designed for controlling the child labour in Pakistan.

\section{Conclusion}

The children are the social asset needed to be respected and protected. However, they are the vulnerable class of the society, and as such becomes easy victim of the societal compromises worldwide including Pakistan. The major issue as being faced by them is the child labour in which they are indulged particularly because of poverty and illiteracy. Such child labour has very severe adverse effects on socio-economic and physical development of the child. Of course, a state is responsible to protect their rights which are being infringed by the issue of child labour. In this context, the Constitution, 1973 has guaranteed them fundamental rights including certain other constitutional rights.

In Pakistan, child labour is not only prohibited, it is discouraged by providing a free compulsory education, self-respect and social welfare. Though, these provisions are healthy sign, but are not comprehensive on child labour particularly for determining the minimum age and nature of work. Even these provisions are not clear, and harmonious with one another. Furthermore, the ordinary laws are not in compatibility mode of the constitutional provisions. Such complications are both about child and child labour definition. So, it is suggested to have a single common standard of these two basic factors in child labour context for saving the children from indulging in child labour in Pakistan.

\section{References}

Acemoglu, D. \& Angrist, J. (1999). How Large are the Social Returns to Education? Evidence from Compulsory Schooling Laws, NBER Working Paper No. 7444, accessed March, 10, 2021, https://www.nber.org/papers/w7444

Angrist Joshua D. and Krueger, Alan B. (1991). Does Compulsory School Attendance Affect Schooling and Earnings? The Quarterly Journal of Economics, Vol. 106, (4), 979-1014.

Anker, R., S. Barge, S. R., \& Joseph, M. P. (1998). Economics of Child Labour in Hazardous Industries of India. New Dehli: Hindustan Publishers.

Basu, K. (1999). Child Labor: Cause, Consequence, and Cure, with Remarks on International Labor Standards. Journal of Economic Literature, 37 (3), 1083-1119.

Brackly, B. (2013). The Global Slavery Index. New York: The Walk Free Foundation. Retrieved from; https://www.walkfreefoundation.org/news/resource/the-global-slavery-index- 2013/

Clark, R. (2011). Child Labor in the World Polity: Decline and Persistence, 1980-2000. Social Forces, Vol. 89, (3), 1033-1055.

Cunningham, H. \& Viazzo.P. P. (eds) (1996). Child labour in historical perspective, 1800-1985: case studies from Europe, Japan and Colombia, Florence, Italy. UNICEF International Child Development Centre.

Edmonds, E,V. (2009). Defining child labour: A review of the definitions of child labour in policy Research. International Labour Office, International Programme on the Elimination of Child 
Labour (IPEC) - Geneva: ILO. Retrieved from https://www.ilo.org/ipecinfo/product/download.do?type=document\&id=11247

Grootaert, C. \& Kanbur, R. (1995). Child Labour: A Review. Policy Research Working Paper 1454, World Bank.

Hindman, H. D. (2009). The World of Child Labour. M.E. Sharpe.

Hort, B. (1989). Work, family, and the state: Child labor and the organization of production in the British cotton industry, 1780-1920. London, UK: London University Press.

Luna, C. In Espinosa, M.C. L. (2019).Children play an important role in society. DSWD Retrieved from, https://pia.gov.ph/news/articles/1029852

International Programme on the Elimination of Child Labour, Retrieved from https://www.ilo.org/Search5/search.do

International Programme on the Elimination of Child Labour. What is child labour, Retreived from, www.ilo.org > ipec > facts > lang--en

Mahmood, M. (2014). The constitution of the Islamic Republic of Pakistan 1973. Lahore: Al Qanoon Publisher

Mosby, Inc (2016). Mosby's Dictionary of Medicine, Nursing \& Health Professions. Elsevier.

Plato. Early Socratic Dialogues. Translated by Trevor, J. S. (1987). Penguin Books.

Prügl, E. (1999). The Global Construction of Gender - Home based work in Political Economy of 20th Century. Columbia University Press.

Rao, K .N. (2020). An analysis of socio-economic conditions of child labourers (A Case study of 'Katedhan Industrial Area' in Rangareddy district, Telangana state). International Journal of Academic Research and Development, Volume 5, (3), 82-87.

Rathus SA (2013). Childhood and Adolescence: Voyages in Development. Cengage Learning.Free Dictionary, https://en.wikipedia.org/wiki/The_Free_Dictionary

Rehman, H. (2011). Elimination of Child Labour. Law and Justice Commission Pakistan, 57-58.

Mustafa, W. (January 27, 2017 Thomson Reuters Foundation Retrieved from https://www.reuters.com/article/us-pakistan-childlabour-idUSKBN15A2O7

Schlemmer (1997). In Augendra Bhukuth(2008). Defining Child Labour: A Controversial Debate Development in Practice. Vol. 18, (3) 385-394,385, Retrieved from https://www.jstor.org/stable/27751932

Seabrook, J. (2001). Children of the Other Worlds. Pluto Press.

UNICEF, Retrieved from https://www.ilo.org/Search5/search.do

The Health and Morals of Apprentices Act, 1802.

The Protection of Children Act, 2012.

The Beedi and Cigar Workers Act, 1966.

The Child Labour Act, 1986.

The Children and Young Persons Act 1933.

The Child Labor Regulation under the Fair Labor Standards Act, 1938.

The Constitution, 1973.

The Majority Act, 1875

The Guardian and Ward Act, 1890.

The Factories Act, 1934.

The Mines Act, 1923.

The Shops and Establishment Ordinance 1969.

The Employment of Children Act, 1991.

The Pakistan National Service Ordinance of 1970.

The Prevention and Control of Human Trafficking Ordinance, 2002.

The United Nations Convention on Rights of Children, 1989.

The Minimum Age Convention, 1973, (No. 138).

The Worst Forms of Child Labour Convention, 1999, (No. 182). 